Article

\title{
Interdisciplinary Collaboration on Green Infrastructure for Urban Watershed Management: An Ohio Case Study
}

\author{
Shawn Dayson Shifflett ${ }^{1}\left(\right.$, Tammy Newcomer-Johnson ${ }^{2}$, Tanner Yess ${ }^{3}$ and Scott Jacobs ${ }^{4, *}$ \\ 1 Oak Ridge Institute for Science and Education (ORISE) Research Participation Program, U.S. Environmental \\ Protection Agency, 26 W. Martin Luther King Drive, Cincinnati, OH 45268, USA; shifflett.shawn@epa.gov \\ 2 Office of Research and Development, National Exposure Research Laboratory, U.S. Environmental Protection \\ Agency, 26 W. Martin Luther King Drive, Cincinnati, OH 45268, USA; newcomer-johnson.tammy@epa.gov \\ 3 Mill Creek Alliance, 1662 Blue Rock St. Cincinnati, OH 45223, USA; tyess@themillcreekalliance.org \\ 4 Office of Research and Development, National Risk Management Research Laboratory, U.S. Environmental \\ Protection Agency, 26 W. Martin Luther King Drive, Cincinnati, OH 45268, USA \\ * Correspondence: jacobs.scott@epa.gov; Tel.: +1-513-569-7223
}

Received: 12 March 2019; Accepted: 3 April 2019; Published: 9 April 2019

\begin{abstract}
Many older Midwestern cities of the United States are challenged by costly aging water infrastructure while working to revitalize urban areas. These cities developed much of their water infrastructure before the Clean Water Act became law and have struggled to mitigate contaminant loading to surface waters. An increasingly common approach to resolving these challenges is the integration of green infrastructure with gray infrastructure improvements to manage point and non-point source pollution. Stakeholder engagement and collaboration during green infrastructure planning can help address impairments and promote community involvement through the revitalization process. Mill Creek watershed in Cincinnati, OH, USA has seen improvement in watershed integrity indicators after being impaired for many decades by flashy hydrology, combined sewer overflows, and water quality degradation. A workshop was conducted to examine how integrated green and gray infrastructure has contributed to improvements in Mill Creek over the past several decades. This effort sought to examine internal and external factors that influence a multi-stakeholder watershed approach to planning, implementing, and evaluating green infrastructure techniques. Community investment and physical infrastructure, access to datasets, and skills and knowledge exchange were essential in improving use attainment in the Mill Creek. Strategic placement of green infrastructure has the potential to maximize water quality benefits and ecosystem services. However, green infrastructure deployment has been more opportunistic due to the diversity of stakeholder and decision maker interests. Future work should consider collaborative approaches to address scaling challenges and workforce development to maximize green infrastructure benefits.
\end{abstract}

Keywords: use-attainment; social network analysis; urban planning; governance; social infrastructure

\section{Introduction}

Watershed management in aging urban cities of the Midwestern United States is an expensive but critical need [1,2]. These cities have unique challenges including flashy hydrology, channelized and buried streams, and combined sewer overflows (CSOs) from merged stormwater and wastewater infrastructure [3-5]. In addition, these watersheds have impervious surface areas ranging from $>10 \%$ to $>26 \%[3,6])$, inter-watershed transfers to meet water resource demands [7], and changing precipitation patterns that challenge resource managers to meet use attainment goals identified through the Clean Water Act. 
Achieving use attainment may be addressed by introducing green infrastructure (GI) in combination with traditional engineering and stormwater management practices $[2,8]$. The term "green infrastructure" was defined by amendment to section 502 of the Federal Water Pollution Control Act as "the range of measures that use plant or soil systems, permeable pavement or other permeable surfaces or substrates, stormwater harvest and reuse, or landscaping to store, infiltrate, or evapotranspire stormwater and reduce flows to sewer systems or to surface waters [9]." GI can help divert pollutants, mitigate flooding, improve groundwater infiltration, and provide some cost savings to private and public expenditures [8]. Strategically placing GI in urban watersheds may extend the benefits of these installations, but current practices have been more opportunistic due to the complex sociopolitical mosaic in which these strategies are deployed.

Siting GI in degraded urban waterways requires careful design, planning, and negotiation by watershed management groups and communities. In the Mill Creek Watershed of Cincinnati, Ohio, USA, GI strategies have incorporated rain gardens, permeable pavement, bioswales, green roofs, land conservation, cisterns, groundwater infiltration installations, stream restoration, and stream daylighting. Daylighting, also referred to as de-culverting, is a radical type of GI that involves the transformation of a buried or piped stream back to an open channel [10-12]. For some communities, these GI implementations have been intended to improve the aesthetics of waterways, while watershed management organizations seek to improve water quality and stormwater management. Two leading organizations involved in planning and implementing GI in Cincinnati are the Municipal Sewer District of Greater Cincinnati (the Sewer District) and the Mill Creek Alliance (MCA). The Sewer District has sought to mitigate CSOs by combining infrastructure upgrades with stream restoration. MCA, a Groundwork USA Trust and advocate for equity in the watershed, has sought to improve ecosystem resiliency and watershed integrity by introducing rain gardens, bioswales, and investing in stream restoration. Rain barrels have also been implemented as part of a pilot effort to research GI incentives [13]. Community engagement has been a high priority for both groups for successful planning and implementation of GI, but more work is needed to understand how these strategies and techniques feed into a watershed-wide approach for use attainment. Furthermore, it is unclear how monitoring and evaluation is utilized once projects have been implemented to better inform future planning and implementiation of GI.

This study is based on a workshop with stakeholders from the MCA, the Sewer District, University of Cincinnati, United States Geological Survey (USGS), United States Environmental Protection Agency (USEPA) Region 5, and EPA Office of Research and Development to discuss designing natural GI through interdisciplinary collaboration. The purpose of the workshop was to examine green infrastructure in the Mill Creek watershed and glean lessons learned that could be shared with other similar communities to move toward strategic placement of GI. A stakeholder network analysis was used to identify stakeholders and how their roles affect the establishment of GI in the Mill Creek Watershed. Additionally, a strength-weaknesses-opportunities-threats (SWOT) analysis was conducted to determine internal versus external and positive versus negative factors affecting GI, such as daylighting Congress Run, a buried tributary within the Mill Creek Watershed (See Supplementary Material Figure S1). Our objectives were to define and to document lessons learned from the workshop regarding internal strengths and weaknesses as well as external opportunities and threats influencing (1) GI planning, (2) implementation, and (3) evaluation. This article broadly synthesizes findings from our approach and identifies research gaps regarding future strategic placement of GI.

\section{Materials and Methods}

\subsection{Study Area Description}

The Mill Creek watershed is a $437 \mathrm{~km}^{2}$ HUC 10 (0509020301) located in southwestern Ohio, USA $\left(-84^{\circ} 29^{\prime} 24^{\prime \prime}, 39^{\circ} 15^{\prime} 0^{\prime \prime}\right.$; see Figure 1; [14]). The Great Miami River basin bounds the watershed in the northwest, the Little Miami River basin to the east, and the Ohio River and direct tributary watersheds 
to the south and west. The total elevation difference from Mill Creek's headwaters in Butler County to the barrier dam in Hamilton County is $107 \mathrm{~m}$. Upper Mill Creek has a wide valley bottom with an approximate width of $2.4 \mathrm{~km}$. Lower Mill Creek narrows considerably and has an extensively modified concrete trapezoidal channel that flows through a highly urbanized, industrial landscape. The four major tributaries are underlain by thinly inter-bedded layers of shale and limestone bedrock, except in the lower confluences of the metropolitan area, where the creek has been armored. Thirty-year average annual precipitation is $1072 \mathrm{~mm}$, but inter-annual precipitation differences have deviated greatly from the average with annual precipitation ranging from $931 \mathrm{~mm}$ to $1861 \mathrm{~mm}$ in the last 18 years [15]. The watershed is highly urbanized with $21.0 \%\left(91.8 \mathrm{~km}^{2}\right)$ impervious surface and approximately $78.9 \%\left(345 \mathrm{~km}^{2}\right)$ developed land as of 2011 [16]. Soils are distributed heterogeneously throughout the watershed but are dominated by well drained to excessively drained urban-Urdothents complexes [17].

The Mill Creek watershed has a complex mosaic of geographical, political, and jurisdictional boundaries. The watershed is divided amongst Hamilton, Butler, and Warren counties. Thirty-six different municipalities are fully or partially within the Mill Creek watershed (see Supplementary Material Figure S2). Within the largest municipality of Cincinnati, Hamilton county recognizes 47 different jurisdictions represented by 52 different community councils (See Supplementary Material Figure S3; [18]). The watershed is also divided into 11 facility planning areas (FPAs) managed by Ohio-Kentucky-Indiana Regional Council of Governments, a Metropolitan Planning Organization that maintains water quality management plan as required by section 208 of the Clean Water Act. The majority (71\%) of watershed falls within the boundary of the Sewer District, which serves a population of $>850,000$ (Figure 1). The Sewer District's boundary crosses into eight different HUC 10 watersheds. Like many midwestern cities, the Sewer District is under consent decree (Civil Action No. C-1-02-107) with the U.S. EPA, the U.S. Department of Justice, and Hamilton County. This legal agreement requires a CSO discharge reduction of 7.6 billion liters per year (or 66\%) by 2019 [19,20]. Before the consent decree, Mill Creek watershed contained over 200 CSOs and sanitary sewer overflows (SSOs), a challenged municipal wastewater treatment plant, numerous industrial point discharges, and deteriorating sewage collection systems [19]. Through the consent decree, the Sewer District developed Project Groundwork, a multi-billion dollar and multi-year initiative to implement hundreds of sewer improvements and stormwater control projects, including implementing green infrastructure [21]. Over the past several decades, these projects and others have helped improve watershed integrity $[19,22]$.

Even with this progress, GI planning and implementation has been challenging due to various social, political, and technical challenges. One example identified was the daylighting of a sub-watershed. Congress Run is a $77.6 \mathrm{~km}^{2}$ HUC 12 (040509020301) with 79.4\% developed land and $35.6 \%$ impervious cover [22]. Congress Run has been listed as a priority project in multiple watershed plans [22,23]. A stretch of the stream was buried in a 183-m corrugated metal culvert under a golf course owned by Duke Energy. Multi-year plans were made to daylight the stream by removing the culvert and studying the effects of restoration, but various barriers delayed implementation and complicated evaluation. These barriers included divergent landowner interest, discovery of underground obstacles, and financial cost. Furthermore, effective and consistent monitoring of these sites in the urban environment presents its own challenges; these include the loss of monitoring equipment due to extreme flows, vandalization of equipment, hazardous stream banks, and lack of ideal spots for flow gages. These collective challenges are significant to the strategic placement and evaluation of GI that influence overall watershed integrity. Thus, Congress Run was presented as a case study to highlight challenges in the planning, implementation, and evaluation of GI in Mill Creek Watershed. 


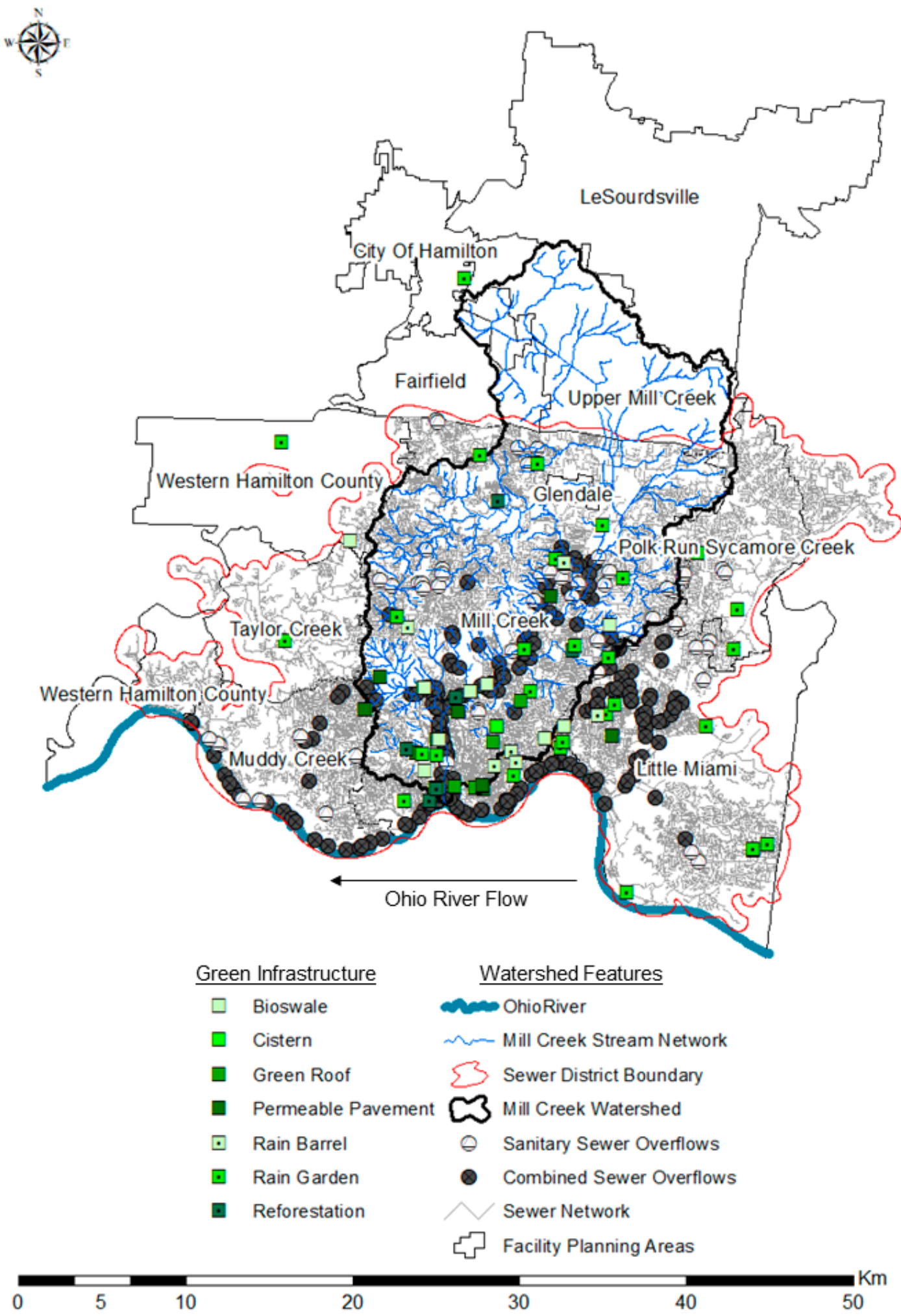

Figure 1. Map layout for Mill Creek Watershed and contributing facility planning areas (FPAs). Locations of combined sewer overflows (CSOs), sanitary sewer overflows (SSOs), and green infrastructure (GI) installations are juxtaposed to demonstrate the complex mosaic of the system's hydrology and its stressors. 


\subsection{Workshop and Follow-Up Meetings}

In September 2017, a meeting was convened in Cincinnati, OH to discuss past GI efforts and identify strengths and weaknesses in the planning, implementation, and evaluation process. The topics covered were both broad and specific. Broadly, attendees discussed some of the regulatory frameworks, public engagement opportunities, and needs for expanding GI. Specifically, Mill Creek and the Congress Run case study combined sewer improvements to meet use-attainment goals with stream restoration and daylighting a failing culvert. Invited participants represented various organizations that were involved in planning, implementation, and evaluation of green infrastructure in the Mill Creek watershed. The participant organizations included EPA Office of Research and Development, EPA Region 5, United States Geological Survey (USGS), the Sewer District, Mill Creek Watershed Council of Communities and Groundwork Cincinnati-Mill Creek (now joined together as the MCA), and the University of Cincinnati.

A stakeholder network analysis was conducted to understand how various stakeholders were affiliated with one another. Researchers and managers are often interested in understanding how social relationships that compose complex governance structures like that of Mill Creek hinder or promote good water resource management practices. Stakeholder network analysis is increasingly being used as a tool in natural resource management to identify critical stakeholders within a network [24-26]. There are many social network analysis techniques [25,27-29], and our effort focused on network affiliation for understanding how different organizations coalesce and diverge from watershed-based goals. Network participants were identified through the workshop and follow-up meetings by creating an inventory of identified partners and collaborators of watershed stakeholders.

A SWOT analysis was conducted to organize relevant concerns raised during the workshop [30]. SWOT is a strategic planning tool for complex situations that aids decision making by condensing information into four categories [30]. In SWOT, internal strengths and weaknesses can include financial resources, efficiency and capacity, structure, image, and others [30]. External opportunities and threats can include regulatory, political, economic, and environmental issues as well as new technologies and social changes, among others [30]. When considering whether a factor was internal or external, participants were asked to share their organization's perspectives. As a result, this SWOT analysis combined the perspectives of multiple individuals from different organizations. Within a year of the workshop, follow-up discussions were held with workshop participants to evaluate the SWOT analysis results and further refine conclusions.

\section{Results}

\subsection{Stakeholder Analysis}

Planning, implementing, and evaluating GI projects has required communities to see value in GI projects. Each municipality has unique goals and priorities based on its community makeup and desire to achieve improved water management outcomes. Within the Mill Creek Watershed, the Sewer District and MCA play a leadership role in planning, implementing, and monitoring green infrastructure. Though the motivation for these two organizations is different, both have been successful in adding GI. Figure 2 demonstrates their network affiliation with local municipalities, government agencies, other non-profits working in the watershed, and additional ad hoc partners that may participate in GI efforts. A clear result of this analysis is that the network is somewhat partitioned between government agencies that interact with the Sewer District and non-profit groups that interact with MCA. These two organizations are connected through their relationship with communities in the Mill Creek Watershed. Though these relationships do not inherently lead to strategic placement of GI for improved watershed integrity, GI implementations were more likely when communities had a relationship with both organizations. Thirteen of the 28 (39\%) communities served by both MCA and the Sewer District had GI installations, whereas only one out of the eight (13\%) communities served strictly by MCA had GI installations (Figure 2). 


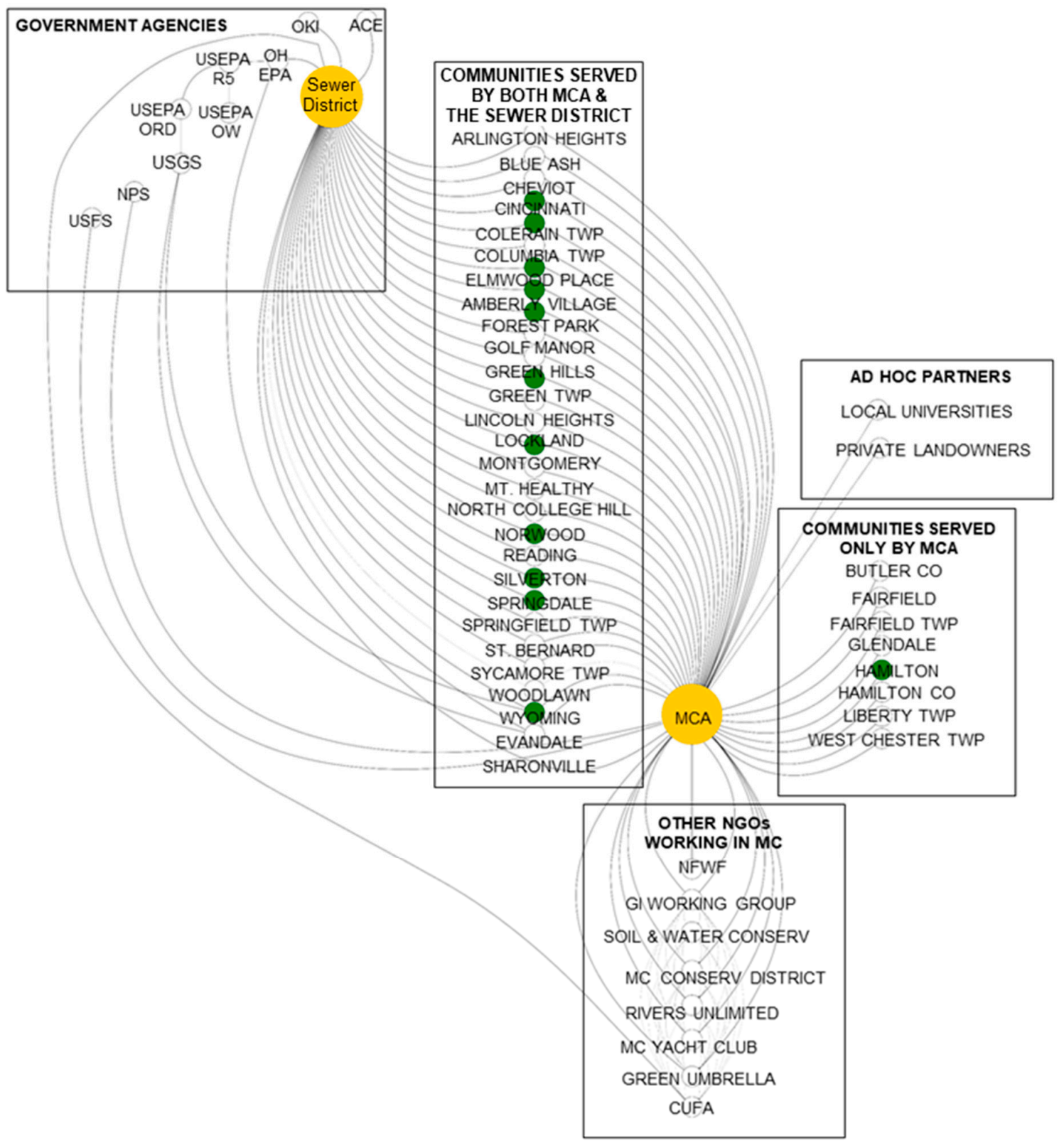

Figure 2. Stakeholder network map for GI planning, implementation, and evaluation in the Mill Creek Watershed. Green nodes are communities with GI installations. Yellow nodes are organizations responsible for planning and implementing GI. Nodes are clustered by organization type (i.e., government agencies versus communities). ACE: Army Corps of Engineers; OKI: Ohio-Kentucky-Indiana Regional Council of Governments; NPS: National Park Service; FWS: US Fish and Wildlife Service; MCA: Mill Creek Alliance; USGS: United States Geological Survey; EPA: United States Environmental Protection Agency; CUFA: Communities United for Action.

For MCA, working in the Mill Creek watershed means partnering with 36 political jurisdictions, interest groups, and community councils, many of whom have different values (Figure 2). Of these 36, only 12 have GI installations, and the largest municipality (Cincinnati) has the most (Figure 2). MCA also partners with other non-profit groups that are not inherently responsible for planning, implementation, or evaluation of GI. These groups tend to have special interest in broadly improving watershed integrity and engaging in river clean-up activities, citizen science water quality monitoring, and building social infrastructure for environmental recreation. To achieve its mission of community empowerment, MCA has several funding sources, including National Park Service (NPS), National Fish 
and Wildlife Service (FWS), Ohio Environmental Protection Agency, and the Sewer District (Figure 2). For the Sewer District, working in the Mill Creek watershed includes collaborating with a variety of stakeholders, contractors, and subcontractors to meet the requirements of the consent decree as well as community interests. Though the Sewer District partners with 43 municipalities, only 28 are within the Mill Creek Watershed (see Figures 1 and 2). The Sewer District is subject to federal and state oversight via the Ohio-Kentucky-Indiana Council of Governments (OKI), the Army Corps of Engineers (ACE), and Ohio EPA. Ohio EPA also receives support for GI from the US EPA through its Regional Green Infrastructure Coordinator, the Office of Water, and the Office of Research and Development.

In the case of daylighting Congress Run, the stakeholder network has been dynamic. Before the assessment began, stakeholders included Mill Creek Watershed Council of Communities, Groundwork Cincinnati, the municipality of Springfield Township, the private landowner (Duke), the land manager (Duke's Hartwell Golf Course), adjacent landowners (Byer Steel), and researchers from University of Cincinnati and US EPA Office of Research and Development. During this process, Mill Creek Watershed Council of Communities and Groundwork Cincinnati combined to form the Mill Creek Alliance (MCA). Simultaneously, there was concern that this stream daylighting and restoration project would negatively impact the experience of golfers due to the wide corridor needed for stream restoration. During the planning efforts, the golf course closed, and the impact to golfers ceased to be a consideration to the restoration project planning and implementation. Changes observed during the study period captured the fluid nature of a stakeholder network seeking to plan and implement GI within a group demonstrating diverse values.

Identifying the boundary of the stakeholder network affiliation came with some difficulty, as has been documented in several stakeholder network assessments [24,29,31,32]. Through the workshop and subsequent follow-up meetings, GI and watershed stakeholders identified their network and explained how they interact within their network. This approach might have meant that some unidentified but meaningful stakeholders were not considered for this stakeholder network analysis. Thus, this analysis does not preclude that other stakeholders may be playing a role in GI planning, implementation, and evaluation for the Mill Creek Watershed. Similarly, this analysis is limited in capturing and predicting the dynamics of the stakeholder network because social networks are constantly changing as connections between stakeholders sever or form [24,33-35]. To this point, the role of individuals who champion watershed integrity and advocate for GI throughout the watershed is worth noting. Several individuals were identified as key players in establishing relationships among communities and organizations. One outstanding question in this stakeholder network analysis is how the networks will change as these key individuals are no longer able to act as champions in the watershed.

\subsection{Green Infrastructure Planning}

\subsubsection{Inventory of GI Plans}

Stakeholders identified comprehensive plans proposing green infrastructure to improve system integrity; however, additional research was needed to identify many of these planning documents (see Table 1). The objectives of these plans included, but were not limited to, expanding stream restoration, improving canopy cover up to $40 \%$, and encouraging the installation of green stormwater management systems to capture, slow, and infiltrate stormwater during moderate and large rain events [22]. Stakeholders broadly identified many strengths, weaknesses, opportunities, and threats to these plans. An internal strength of incorporating GI into formal watershed and other location-based plans is that it can provide a roadmap for strategic placement of GI. An additional strength of formal plans is that they can improve continuity of vision across changes in political administrations as well as local organizational turnover. An external opportunity from these plans is they can enable and strengthen eligibility for funding GI implementation and evaluation (e.g., the Nine-element Nonpoint Source Implementation Strategic Plan for Congress Run-Mill Creek HUC-12 enables eligibility for Clean Water Act (CWA) section 319 grant funding [22,36]). An internal weakness was the lack of formalized 
accountability in GI plans (e.g., the Green Cincinnati Plan lacks a structure for accountability [37]). Collectively, this SWOT analysis indicated that taking a careful inventory of existing plans at the watershed scale may be critical to achieving improved use-attainment in waterways, but these plans need to be comprehensively reviewed by decision makers for long-term success. Likewise, creating these inventories can better inform where gaps exists in the planning, implementation, and evaluation of GI at the watershed scale.

Table 1. National, regional, and local strategic plans affecting GI in the Congress Run-Mill Creek Watershed.

\begin{tabular}{|c|c|c|c|c|}
\hline & Scale & Strategic Plan Title & Lead Organization & Purpose \\
\hline National & $\begin{array}{l}\text { Ohio River } \\
\text { Watershed } \\
\left(528,360 \mathrm{~km}^{2}\right)\end{array}$ & $\begin{array}{l}\text { A Framework for } \\
\text { Ecosystem Restoration of } \\
\text { the Ohio River and its } \\
\text { Watershed [38] }\end{array}$ & $\begin{array}{l}\text { Ohio River } \\
\text { Foundation }\end{array}$ & $\begin{array}{l}\text { Restore the Ohio River and } \\
\text { its watershed. }\end{array}$ \\
\hline Regional & $\begin{array}{l}\text { Butler, Clermont, } \\
\text { Hamilton, and } \\
\text { Warren Counties in } \\
\text { Ohio }\left(4532 \mathrm{~km}^{2}\right)\end{array}$ & $\begin{array}{l}\text { Water Quality } \\
\text { Management Plan for } \\
\text { Butler, Clermont, } \\
\text { Hamilton, and Warren } \\
\text { Counties in Ohio [39] }\end{array}$ & OKI & $\begin{array}{l}\text { Manage water quality in the } \\
\text { greater Cincinnati region. }\end{array}$ \\
\hline \multirow[t]{6}{*}{ Local } & $\begin{array}{l}\text { Cincinnati } \\
\text { Sewershed } \\
\left(751 \mathrm{~km}^{2}\right)\end{array}$ & $\begin{array}{l}\text { Wet Weather Improvement } \\
\text { Plan [40] }\end{array}$ & $\begin{array}{c}\text { Metropolitan } \\
\text { Sewer District of } \\
\text { Greater Cincinnati }\end{array}$ & $\begin{array}{l}\text { Fulfill consent decree } \\
\text { requirements pertaining to } \\
\text { submission of the CSO Long } \\
\text { Term Control Plan Update } \\
\text { and the Capacity Assurance } \\
\text { Program Plan. }\end{array}$ \\
\hline & $\begin{array}{l}\text { Mill Creek } \\
\text { Watershed } \\
\left(440 \mathrm{~km}^{2}\right)\end{array}$ & $\begin{array}{l}\text { Lower Mill Creek } \\
\text { Watershed Action Plan [23] }\end{array}$ & MCA & $\begin{array}{l}\text { Improve "water quality and } \\
\text { ecological health in the } \\
\text { Lower Mill Creek Watershed } \\
\text { that will, in turn, create } \\
\text { more livable neighborhoods } \\
\text { and provide public health, } \\
\text { environmental, social, and } \\
\text { economic benefits for many } \\
\text { years to come." }\end{array}$ \\
\hline & $\begin{array}{l}\text { Mill Creek } \\
\text { Watershed } \\
\left(440 \mathrm{~km}^{2}\right)\end{array}$ & $\begin{array}{l}\text { Mill Creek Watershed } \\
\text { Greenway Trail Master } \\
\text { Plan [41] }\end{array}$ & MCA & $\begin{array}{l}\text { Improve water quality and } \\
\text { floodplain management and } \\
\text { contribute to economic } \\
\text { well-being. }\end{array}$ \\
\hline & $\begin{array}{l}\text { City of Cincinnati } \\
\left(206 \mathrm{~km}^{2}\right)\end{array}$ & $\begin{array}{l}\text { Plan Cincinnati; A } \\
\text { Comprehensive Plan for } \\
\text { the Future [42] }\end{array}$ & $\begin{array}{l}\text { Cincinnati City } \\
\text { Council }\end{array}$ & $\begin{array}{l}\text { "Redefines our city and } \\
\text { what it means to be a } \\
\text { thriving urban city." }\end{array}$ \\
\hline & $\begin{array}{l}\text { City of Cincinnati } \\
\left(206 \mathrm{~km}^{2}\right)\end{array}$ & $\begin{array}{l}2018 \text { Green Cincinnati } \\
\text { Plan [37] }\end{array}$ & $\begin{array}{l}\text { Mayor's Steering } \\
\text { Committee }\end{array}$ & $\begin{array}{l}\text { Provides a roadmap guide } \\
\text { for transitioning the area } \\
\text { into a more sustainable, } \\
\text { equitable, and resilient city. }\end{array}$ \\
\hline & $\begin{array}{l}\text { Congress Run } \\
\text { Watershed } \\
\left(77.6 \mathrm{~km}^{2}\right)\end{array}$ & $\begin{array}{l}\text { Nonpoint Source } \\
\text { Implementation Strategic } \\
\text { Plan; Congress Run-Mill } \\
\text { Creek HUC-12 [22] }\end{array}$ & MCA & $\begin{array}{l}\text { Prioritize nonpoint source } \\
\text { pollution reduction } \\
\text { strategies and projects in the } \\
\text { Congress Run-Mill Creek } \\
\text { HUC-12. This plan enables } \\
\text { eligibility for Clean Water } \\
\text { Act section } 319 \text { grant } \\
\text { funding. }\end{array}$ \\
\hline
\end{tabular}

\subsubsection{Social Infrastructure for GI Planning}

There was consensus among the workshop participants that an internal strength of GI planning is that it provides communities an opportunity to participate in the planning process. Community-based planning has provided the opportunity for communities to provide input, but it has been met with 
mixed success [33-46]. The Sewer District has been mandated to conduct regular townhalls to incorporate community values into their GI planning process. However, some local organizations have demanded greater transparency from the Sewer District (e.g., Communities United for Action), and communities regularly express frustration about rising sewer costs. In contrast, MCA is not providing sewer services and is not federally mandated to plan or implement green infrastructure, thus they have more flexibility to invest in their social infrastructure (community relationships, education programs, and green workforce development). MCA has sought to implement GI when communities or individual landowners have expressed interest in protecting and enhancing the value of the Mill Creek and its tributaries. Though the Sewer District and MCA are structurally different, they both depend on social infrastructure investment when seeking to implement GI at the watershed scale. The challenge of effectively building social infrastructure has been identified by other research efforts in the Midwest [47-50]. Poor acceptance of using GI strategies has occurred most frequently in communities with lower socioeconomic status $[48,50]$. These communities may not have valued GI strategies because they cannot support increased housing costs and property values that come with these implementations [51], or because other environmental justice issues take precedence. Thus, planning GI efforts may need to be reconciled with other community needs.

\subsubsection{Funding and Governance in GI Planning}

Future funding for GI planning was identified as an external threat in the workshop and follow up discussions. This threat was tied to the challenge in quantifying the benefits for GI. Funding for planning may depend on the structure and efficacy of local governments, sewer districts, metropolitan planning organizations, and non-profits. Funding for planning GI installations in Mill Creek has historically come from multiple sources. The Sewer District has derived some of its funds for GI planning through grants and low-interest construction loans but mainly through customer billing. However, Cincinnati has one of the highest quarterly billing rates of all major cities in the state of Ohio [52]. Furthermore, the Sewer District, like most municipal sewer districts in the Midwest, contracts out design and planning of GI due to a limited in-house workforce capacity (Figure 2). MCA, a non-profit organization, does not receive dedicated funding for GI planning but does receive funding for GI implementations through Ohio EPA, Ohio Department of Natural Resources, National Fish \& Wildlife Foundation, National Park Service, US Forest Service, and through the Sewer District. Funding mechanisms were commonly identified as a challenge in GI planning, as many Midwestern cities implement GI under conditions of competing needs. As a result, few funds have been dedicated to helping cities develop good GI plans that lead to meaningful GI installations [53]. Though this phase of the process might be viewed as sweat equity for these organizations, improving funding for the planning process has the potential to improve strategic implementation.

\subsubsection{Tools and Models for GI Planning}

There are multiple models and datasets available to aid in GI planning, though it is unclear how often these are used in urban Midwestern watersheds. The EPA has developed tools such as the Stormwater Calculator (https:/www.epa.gov/water-research/national-stormwater-calculator), which estimates the annual amount of rainwater and frequency of runoff from a specific site to help planners and property owners improve stormwater management. The Stormwater Calculator uses data from national databases that provide soil, topography, rainfall, and evaporation information for a chosen site. The user supplies information about the site's land cover and selects low impact development (LID) controls they would like to use. The LID controls include seven green infrastructure practices. Another EPA tool is the Green Infrastructure Wizard (GIWiz; https:/www.epa.gov/sustainability/giwiz), which is a digital repository of GI-related resources and tools. None of the workshop participants were actively using these EPA tools in their day to day work. The Sewer District contracted with the Midwest Biodiversity Institute to develop an Integrated Prioritization System to prioritize their response to the CSO Consent Decree and for Capital Improvement Planning [54]. The Integrated Prioritization System 
was able to identify sites and stream reaches where use attainment was substantially good and bad, thus allowing the Sewer District to develop plans for sites with high degradation. This approach may be equally as meaningful for other urban Midwestern watersheds seeking to integrate GI to improve use attainment. However, there is a need to improve GI planning tools and models for public use and decision making.

Another challenge to the use of tools and resources is opportunistic pressure. Some of these tools may require substantial technical expertise and time investment, and this can be a limiting factor for organizations seeking to plan strategically. Stakeholders with MCA have used the EJSCREEN Tool (https://www.epa.gov/ejscreen) to identify areas with low-income or minority populations to support educational programs and grant writing. Older cities in the Midwestern United States have unique challenges in improving environmental conditions that may be addressed in part by resilient natural GI in combination with traditional engineering and stormwater management practices. Many community plans will commit to GI efforts for aesthetic improvement, but awareness of how it impacts use attainment remains unclear and under prioritized.

\subsubsection{Education and GI Planning}

Stakeholders identified the lack of educational programs and workforce development programs in GI planning as a threat and a weakness. University of Cincinnati's School of Planning does offer a Green Roofs Certificate program, which is one of the first in North America (https://daap.uc. edu/academics/sop/overview/green-roofs-cert). There is also the option to become certified as an Accredited Green Roof Professional (GRP) with the organization Green Roofs for Healthy Cities (https: //greenroofs.org/grp-faq/). GI planning requires a diverse knowledge base including fundamentals of urban planning, ecology, hydrology, and chemistry. Furthermore, planners may need knowledge of landscape management as well as a capacity to develop social infrastructure with communities. More research is needed to understand how emerging areas of water management and GI can be translated to institutionalized and accredited programs for improved workforce development. Lastly, it is unclear if organizations are positioned to hire and expand their workforce to incorporate trained individuals. This issue is not new but remains a challenge for the planning process.

\subsection{Green Infrastructure Implementation}

\subsubsection{Social Infrastructure for GI Implementation}

Stakeholders identified GI implementation as an area for general improvement for Midwestern urban watersheds. Implementation includes three phases: the engineering design, construction, and maintenance of GI projects. Some of the long-term strategic plans were written for ideal circumstances (Table 1), which rarely reflect the sociopolitical and environmental conditions in urban midwestern watersheds. Support for GI has existed at many of the various levels of governance (i.e., municipalities, jurisdictions, counties, state, and federal), but implementations have tended to be opportunistic based on funding and land availability. Land dedicated to GI must either be purchased, donated, occur on public property, or require some agreement between landowners and organizations seeking to install GI. Similarly, many of these sites are highly degraded from historical land use practices and require rehabilitation before GI can be installed. Thus, stakeholders pointed out that threats and weaknesses to GI implementation have been multifold. First, there may be limited funding for GI project completion, which may not include unexpected obstacles such as remediation of buried hazardous materials. Second, implementation of GI is typically achieved by a menagerie of contractors such as engineering firms for design, construction companies for building, and park department employees or other organizations for maintenance. If these diverse teams are not well-coordinated, there is a risk of miscomunication and inefficient GI management, leading to apprehension and a lack of clarity regarding governance. GI maintenance and upkeep may be neglected without a clear plan, funding source, and responsible party. Third, stakeholders noted that GI implementation has required 
a unique combination of skills, and as a result, creating job descriptions and bids for GI implementation has been challenging. Consequently, this aspect of GI may be an area for growth if watershed scale approaches are desired.

\subsubsection{Funding and Governance for GI Implementation}

Stakeholders expressed that funding was both a weakness and a threat to GI implementation. These challenges were partly attibuted to difficulties in predicting costs, benefits, and tradeoffs of GI in Midwestern cities. GI tends to be implemented under strict fiscal austerity [53]. As a result, GI implementations that could be effective at the watershed scale may not be installed due to associated costs. In their place have been smaller piecemealed GI efforts that may have impacts with a more limited footprint. For example, during the study period, the Lick Run Project in the lower Mill Creek Watershed was under construction to daylight a one-mile $(1.6 \mathrm{~km})$ reach and eliminate 1.5 billion liters of CSO releases annually. The Lick Run stream restoration has been estimated to cost $\$ 193$ million USD for design and construction [21]. However, this project has not been without its complications. The project included funding for land acquisition, but that funding was insufficient to acquire the number of properties needed to meet the original plan for this project. Similarly, strategic planning may require GI installations ubiquitously throughout the watershed, but not all communities may have the economic capacity to meet the costs of GI. In Mill Creek, community groups must be able to contribute $25 \%$ of the total project cost to qualify for certain grants. This cost may be too substantial for communities where the benefits of GI installations and importance of environmental integrity are not a high priority. Therefore, successful implementation is contingent upon key decision makers, landowners, and social networks that bring these individuals together around community goals that can include GI elements. As such, GI has been implemented where spatially possible and where landowners and decision-makers were willing to support environmental resilience and improved water quality downstream.

Stakeholders identified the lack of role clarity in governance of GI implementations as a weakness. Efforts exist to support structured decision making for communities, but the impetus for implementation may need to originate from within local communities to successfully engage in a process that supports GI that is coordinated at a wider scale [55-57]. Watershed-wide implementation coordination exists primarily through regional organizations such as OKI [22,49]. However, implementation on private land has depended upon support from landowners who must weigh the advantages and disadvantages of changes made to the landscape. Strategic planning at a regional level supports a watershed approach but may lack authority and responsibility that rests with ownership and control of property. Furthermore, stakeholders expressed that implementation of GI is frequently site specific due to local soil conditions and existing infrastructure and can be difficult to translate to other sites. A need for streamlining GI implementations could improve this barrier, but other research efforts have noted that this may create divides between GI policy and practice $[56,58]$. As a result, it is unclear how governance hierarchies would be able to provide guidance on sustainable management [59]; however, the workshop participants advised that a clear plan and common understanding of who is responsible for design, construction, and maintenance is critical.

\subsubsection{Education and GI Implementation}

GI implementation was identified as an opportunity to create market growth, jobs for workers with a variety of educational backgrounds, and strengthened community engagement. There is a need to improve education for professionals engaged in GI implementation and for communities to understand the function and maintenance of their GI assets. Recent reports have demonstrated looming shortages in GI and water skilled workers capable of engineering design, construction, and maintenance [60]. This gap represents an opportunity for academic institutions and workforce development programs to engage students in multidisciplinary learning programs. Similar efforts have been documented in the assessment of renewable energy [61]. Certification programs for professionals do exist (e.g., 
National Green Infrastructure Certification Program for construction and maintenance [62]), but they are relatively new, and their impact is unclear. The workshop participants also shared the need to better define what skills are needed for the three phases of GI implementation as well as the need to develop language for job descriptions. Much like the planning phase, installing GI implementations can require a diverse skillset including knowledge on hydrology, ecology, engineering, construction, and landscape management. Similarly, investment in community education and outreach regarding the potential benefits of GI is needed to inform citizens who, in turn, have influence over planning and investments in restoration or protection of source and recreational waters. Many workshop participants noted that they themselves had not been well versed in GI terminology (e.g., rain garden, pervious pavement, etc.) until they became engaged through their occupations. Thus, developing language specific to GI implementation has been limited. This may be an artifact of institutional knowledge delay. Stakeholder institutions that are less fluid in their adaptation to modern water management strategies may have to play catch up with GI applications as a strategy for improved watershed integrity.

\subsection{Green Infrastructure Evaluation}

\subsubsection{Inventory of GI Evaluations}

Through the workshop and follow-up conversations, GI evaluation was identified as an area where more work is needed, which matches larger multi-decade trends calling for better evaluation of the mult-billion ecological restoration industry $[12,63,64]$. However, workshop participants considered evaluating GI effectiveness to be a lower priority than implementing additional GI and sewer repairs. GI evaluation is composed of monitoring the site for metrics relevant to project goals, analyzing monitoring results, and potential adaptive management if needed. Though these metrics can be quantified through a variety of experimental designs, workshop participants advised that the evaluation of use attainment in waterways was a high priority $[19,22]$. This prioritization may be largely attributed to the governance structures surrounding GI. Because regulations specific to GI have only recently been implemented (e.g., H.R. 7279 [9]), surface water regulations through the CWA have been the focus of evaluating GI impacts. In Mill Creek, multiple water quality management practices (CSO reduction and GI addition) were integrated together, which made it challenging to quantify water quality improvements attributable to GI at a watershed scale. Published performance values for GI could be used to estimate the benefits, but these are typically transferred from a different location, and there is uncertainty regarding the appropriateness of these values given potential differences in climate, soils, and other factors $[65,66]$. Stakeholders pointed out that few pilot scale studies have been conducted in southwestern Ohio and were uncomfortable applying general knowledge at site scale. Consequently, there is uncertainty regarding how individual GI projects impact the Mill Creek at a watershed scale. Understanding the watershed-scale effects of green infrastructure is an emerging science [67].

Evaluation of waterways in Mill Creek Watershed has been largely divided between many stakeholder organizations-a common trend in Midwestern cities [53]. The purposes of these sampling efforts vary, as do the methods, quality control, and data reporting procedures used. Organizations involved in watershed management and implementing GI (e.g., the Sewer District, Ohio EPA, and MCA) conducted longer-term monitoring of status and trends using standard methods over a broad spatial scale $[19,68]$. In contrast, research focused organizations (e.g., academic institutions and EPA Office of Research and Development) were more likely to use novel methods for ad hoc shorter-term, smaller-scale experiments examining the effectiveness of specific practices or elucidating mechanisms (e.g., [69]). The Sewer District has conducted long-term monitoring to demonstrate potential improvements from management activities throughout the sewershed. Ohio EPA has also routinely monitored surface waters throughout the watershed to understand if these resources are meeting CWA water quality criteria (https://www.epa.ohio.gov/dsw/bioassess/ohstrat). MCA's monitoring efforts have been supported by trained citizen scientist volunteers who conduct monthly water quality assessments for nine months per year on the following parameters: conductivity, $\mathrm{pH}$, 
nitrates, total phosphorus, bacteria (Escherichia coli and total coliforms), Chlorophyll-a, and optical whiteners [68]. The goal of these assessments is to identify potential improvement in the watershed through GI and restoration efforts of the organization and provide some feedback on where to focus future efforts. However, these evaluations are not tied directly to a specific GI installation. EPA ORD and its contractors collect water samples in stream reaches of Mill Creek for method development and performance evaluation, but these efforts are not designed to inform the watershed planning process. The University of Cincinnati and other academic institutions also have student researchers seeking to evaluate GI in Mill Creek, but like ORD, these efforts are not intended to inform planning within the watershed. Though these organizations all have different motivations, improved collaboration between organizations may lead to a better understanding of how waterways in Mill Creek Watershed are changing as well as provide feedback mechanisms for how different land management practices, including GI, are affecting reaches within the watershed.

Several robust indicators comprised of chemical, toxicological, and ecological measures have been used to evaluate the Mill Creek watershed as various management actions such as sewer repairs and GI were applied (Table 2). Ohio EPA conducted surveys in 1992, 1997, and 2014, and the Midwest Biodiversity Institute (MBI) conducted surveys under contract with the Sewer District in 2011, 2013, and 2016 using these indicators to determine whether sites in the Mill Creek watershed were meeting their designated uses. Determining designated use attainment was done by examining whether environmental parameters and indicators met criteria specified by Ohio's Water Quality Standards under the Clean Water Act for aquatic life and recreation. Recreational use attainment status was determined by the fecal indicator bacteria, E. coli, which indicates the potential presence of pathogenic organisms associated with fecal contamination $[19,70]$. Multi-metric biological indicators were used to determine the health of the macroinvertebrate community \{e.g., Invertebrate Community Index (ICI); [19,71,72]\}, fish community \{e.g., Index of Biotic Integrity for fish assemblages (IBI); [19,72-74] and the Modified Index of Well-Being (MIwb); $[54,75,76]\}$, and habitat quality [Qualitative Habitat Evaluation Index (QHEI)] to assess whether the aquatic life criteria were being met. Additionally, MBI synthesized the results of multiple indicators and previous surveys into an area of degradation to attainment (ADV/AAV) ratio and restorability score [19,54]. The ADV/AAV ratio showed significant improvement in stream miles achieving use attainment in Mill Creek from 1992 to 2016 [19,54,77]. The purpose of the restorability score was to help prioritize sites for restoration; sites that are closer to use attainment have higher restorability scores [54]. These indicators are complex but have provided important insight to how watershed integrity is improving in the area. As a result, there is an opportunity to see if these metrics can capture the impact of GI.

Table 2. GI related indicators that have been used within Congress Run-Mill Creek Watershed [19,54].

\begin{tabular}{cl}
\hline Indicator & \multicolumn{1}{c}{ Description } \\
\hline $\begin{array}{c}\text { Escherichia coli }(E . \\
\text { coli) criterion }\end{array}$ & $\begin{array}{l}\text { Recreational water quality criteria are based on the amount of E. coli bacteria present in } \\
\text { a water sample. Levels of } E \text {. coli indicate fecal contamination and the potential presence } \\
\text { of pathogenic organisms. }\end{array}$ \\
\hline $\begin{array}{c}\text { Invertebrate } \\
\text { Community Index } \\
\text { (ICI) }\end{array}$ & $\begin{array}{l}\text { Aquatic life water quality criteria are based in part on the ICI, which uses the } \\
\text { abundance and diversity of macroinvertebrates (such as mayflies, caddisflies, dipteran, } \\
\text { and tolerant organisms) to determine the health of the macroinvertebrate assemblage. }\end{array}$ \\
\hline $\begin{array}{c}\text { Index of Biotic } \\
\text { Integrity for fish } \\
\text { assemblages (IBI) }\end{array}$ & $\begin{array}{l}\text { Aquatic life water quality criteria are based in part on the IBI, which expresses the } \\
\text { diversity and condition of a site's fish community. }\end{array}$ \\
\hline $\begin{array}{c}\text { Modified Index of } \\
\text { Well-Being (MIwb) }\end{array}$ & $\begin{array}{l}\text { Aquatic life water quality criteria are based in part on the MIwb, which is applicable in } \\
\text { assemblage measures including numbers, biomass, and two diversity indices (e.g., } \\
\text { Shannon Index). The MIwb reflects the overall diversity and productivity of the fish } \\
\text { population and frequently responds before the IBI to improvements in water quality } \\
\text { and habitat. }\end{array}$ \\
\hline
\end{tabular}


Table 2. Cont.

\begin{tabular}{cl}
\hline Indicator & \multicolumn{1}{c}{ Description } \\
\hline $\begin{array}{c}\text { Qualitative Habitat } \\
\begin{array}{c}\text { Evaluation Index } \\
\text { (QHEI) }\end{array}\end{array}$ & $\begin{array}{c}\text { QHEI is a qualitative habitat evaluation assessment tool that identifies habitat variables } \\
\text { that are important for attainment of the Ohio aquatic life criteria. }\end{array}$ \\
\hline $\begin{array}{c}\text { Area of Degradation } \\
\text { to Attainment } \\
\text { (ADV/AAV) }\end{array}$ & $\begin{array}{l}\text { The ADV/AAV ratio can be used to demonstrate the magnitude and extent of changes } \\
\text { in condition along segments between sampling years. }\end{array}$ \\
\hline $\begin{array}{c}\text { Restorability Score } \\
(1-100)\end{array}$ & $\begin{array}{l}\text { To ease the interpretation of complex environmental data, individual stressors and } \\
\text { responses were ranked on a 1-100 scale linked to the tiered aquatic life uses codified in } \\
\text { Ohio's water quality standards for prioritizing sites for restoration. }\end{array}$ \\
\hline
\end{tabular}

Though GI evaluation has not been prioritized in urban midwestern cities, substantial research has been conducted to show how effective various forms of GI can be in the Midwest and elsewhere [69,78-81]. In Shepherd Creek, a tributary of the Mill Creek watershed, Shuster and Rhea (2013) evaluated the effect of a rain barrel incentive program on local hydrology and found that parcel level GI could add small but significant decreases in runoff volume [78]. Efforts are ongoing in Congress Run to determine the impact of daylighting streams on surface water quality and hydrology. In northeastern Ohio, a paired sub-catchment study evaluating voluntary introduction of GI including rain barrels, bioretention cells, and rain gardens demonstrated that these efforts have a significant impact on peak flows in areas with small parcel sizes compared to larger lots [79]. In Missouri, a nine-month evaluation of green roofs planted with Sedum spp. demonstrated a 60\% reduction in runoff volume relative to an impervious surface [69]. In the mid-Atlantic, watersheds with significantly more GI were found to have significantly lower (44\%) peak runoff with less flashy hydrology [80]. Eckart, McPhee, and Bolisetti (2017) reviewed case studies of GI and found that many implementations can be successful depending on their location, local rainfall patterns, and relative area of contribution [81]. However, these authors also noted that there was still a significant amount of information unknown [81]. These efforts demonstrate that GI can have significant impact on watershed hydrology, and more research is needed to eliminate uncertainties. Whether this research will be driven by creating better GI plans, installing GI at locations where it can have the greatest impact, or increasing financial resources available for GI evaluation remains unclear.

\subsubsection{Social Infrastructure and GI Evaluation}

Because evaluation is largely focused on informing how GI has impacted local hydrology and water quality, less knowledge exists on whether this information is meaningful to communities that adopt or are considering adopting GI. Stakeholders noted that this information could be meaningful to decision makers and presented it as a future opportunity for GI research. Unfortunately, gathering these data by the federal government is limited by the Paperwork Reduction Act of 1980 and will remain a gap unless external stakeholders survey the communities in the planning process to understand what factors of GI effectiveness are important. Likewise, integrated socioecological metrics may be needed to integrate both community satisfaction with GI and use-attainment metrics. At the national scale, socioecological indices have been linked to watershed integrity assessments for ecosystem services and community well-being [82,83]. Future work evaluating how GI impacts social infrastructure could provide insight into what communities value in their green space and could better inform GI planning if they are sufficiently sensitive to urban watersheds.

\subsubsection{Funding and Governance for GI Implementations}

Stakeholders pointed to a lack of sufficient funding for evaluation of GI as a weakness, but because it has a lower priority when compared to expanding implementation, evaluation will likely continue to be underfunded in many Midwestern urban cities. This approach carries a general risk 
as GI is expanded as a watershed management strategy, but that may be acceptable if cities are meeting use-attainment goals. Because funding for GI has generally come from private sources, sewer districts, or non-profit groups, there is little impetus to evaluate how these structures impact the local environment and the watershed. Stakeholders generally agreed that improving waterways' use attainment status was more critical than understanding how green approaches affected the integrity of the entire watershed. In Mill Creek watershed, some funds have been available to academic institutions to conduct assessments of GI, but those projects are likely focused on individual installations and do not focus on improvement in the basin. Similarly, some research is completed by USGS and the USEPA Office of Research and Development, but this research is rarely intended to inform the planning process or provide insight on how GI may improve watershed integrity. Therefore, the impact of a mixed GI approach on watershed integrity in Midwestern urban cities is likely to continue being a knowledge gap. A potential solution to this problem would be to establish long-term study sites designed to understand the impacts of GI, as has been established for agricultural practices in the Chesapeake Bay (e.g., [84]). However, these efforts require dedicated funding and local support for long-term research.

\section{Conclusions}

GI continues to show promise as a watershed management strategy. In the Mill Creek watershed of southwestern Ohio, there are many stakeholders working to expand GI within the watershed through a strategic planning process. However, interdisciplinary collaboration between organizations to achieve a strategic implementation has had many hurdles. Effective planning and implementation of GI has required an established and positive relationship with multi-scale stakeholders such as individual landowners, community groups, and larger municipalities. Deploying GI opportunistically may be sufficient for improving use-attainment in local waterways, but it is difficult to distinguish grey infrastructure improvements in the watershed from the GI additions. These hurdles are symbolic of the disconnect among the planning process, the implementation, and the evaluation.

There are many tools available for planning, implementation, and evaluation of GI. However, it is unclear how these tools are being used by community planners and GI implementers to identify the ideal location for various GI installations. Strategic planning may require GI installations ubiquitously throughout the watershed, but not all communities may have the economic capacity to meet the costs of GI that could impact watershed integrity metrics. This contrast in strategic placement and community need demonstrates why GI has become more opportunistic. More information is needed to find an intersection where both use-attainment metrics and community needs are being met.

Similarly, a better confluence is needed between funding mechanisms and governance hierarchies for GI. Many midwestern urban cities implement GI as a watershed management strategy to achieve use attainment in urban waterways. However, fiscal austerity in these cities results in watershed managers seeking balance between what is feasible and what has been planned. Improved guidance on how GI is planned, managed, and evaluated has the potential to streamline some of the discordance between planning and implementing. However, this will require funding for GI evaluation to identify best practices.

Workforce development is a critical need for GI. More individuals with knowledge and technical skills specific to the planning, implementing, and evaluation of GI are needed to ensure GI can evolve with grey infrastructure improvements. Programs have begun to expand and provide opportunities in the planning of GI, but more research is needed to understand how emerging areas of water management and GI can be translated to institutionalized and accredited programs for improved workforce development. However, stakeholder organizations will need to be positioned to hire and expand their workforce to incorporate trained individuals.

Supplementary Materials: The following are available online at http://www.mdpi.com/2073-4441/11/4/738/s1, Figure S1: Summary of SWOT Analysis, Figure S2: Thirty-six different municipalities are fully or partially within the Mill Creek watershed, Figure S3: Within the largest municipality of Cincinnati, Hamilton County recognizes 47 different jurisdictions represented by 52 different community councils. 
Author Contributions: S.D.S., S.J. contributed to paper conceptualization. S.D.S., T.N.-J., T.Y., and S.J. contributed to formal analysis, investigation, and writing-reviewing and editing.

Funding: This research was supported in part by the Oak Ridge Institute for Science Education through Interagency Agreement No. DW-8992433001 between the U.S. Department of Energy and the U.S. Environmental Protection Agency.

Acknowledgments: The authors thank Kate Mulvaney and Brian Dyson for technical review of this manuscript. The views expressed in this paper are those of the authors and do not necessarily represent the views or policies of the U.S. Environmental Protection Agency.

Conflicts of Interest: The authors declare no conflict of interest.

\section{References}

1. United Nations Department for Economic and Social Affairs. Sustainable Development Goals Report; United Nations: New York, NY, USA, 2017; ISBN 978-92-1-101368-9.

2. Kaushal, S.; McDowell, W.; Wollheim, W.; Johnson, T.; Mayer, P.; Belt, K.; Pennino, M. Urban Evolution: The Role of Water. Water 2015, 7, 4063-4087. [CrossRef]

3. Shuster, W.D.; Bonta, J.; Thurston, H.; Warnemuende, E.; Smith, D.R. Impacts of impervious surface on watershed hydrology: A review. Urban Water J. 2005, 2, 263-275. [CrossRef]

4. Kaushal, S.S.; Belt, K.T. The urban watershed continuum: Evolving spatial and temporal dimensions. Urban Ecosyst. 2012, 15, 409-435. [CrossRef]

5. Walsh, C.J.; Roy, A.H.; Feminella, J.W.; Cottingham, P.D.; Groffman, P.M.; Morgan, R.P. The urban stream syndrome: Current knowledge and the search for a cure. J. N. Am. Benthol. Soc. 2005, 24, 706-723. [CrossRef]

6. Schueler, T.R.; Fraley-McNeal, L.; Cappiella, K. Is impervious cover still important? Review of recent research. J. Hydrol. Eng. 2009, 14, 309-315. [CrossRef]

7. Emanuel, R.E.; Buckley, J.J.; Caldwell, P.V.; McNulty, S.G.; Sun, G. Influence of basin characteristics on the effectiveness and downstream reach of interbasin water transfers: Displacing a problem. Environ. Res. Lett. 2015, 10, 124005. [CrossRef]

8. Rexhausen, J. Evaluation of Green Alternatives for Combined Sewer Overflow Mitigation: A Proposed Economic Impact Framework and Illustration of Its Application; U.S. Environmental Protection Agency: Washington, DC, USA, 2013; p. 44.

9. Gibbs, B.H.R. 7279-115th Congress (2017-2018): Water Infrastructure Improvement Act; 115th Congress: Washington, DC, USA, 2019.

10. Neale, M.W.; Moffett, E.R. Re-engineering buried urban streams: Daylighting results in rapid changes in stream invertebrate communities. Ecol. Eng. 2016, 87, 175-184. [CrossRef]

11. Wild, T.C.; Bernet, J.F.; Westling, E.L.; Lerner, D.N. Deculverting: Reviewing the evidence on the 'daylighting' and restoration of culverted rivers. Water Environ. J. 2011, 25, 412-421. [CrossRef]

12. Newcomer Johnson, T.; Kaushal, S.; Mayer, P.; Smith, R.; Sivirichi, G. Nutrient Retention in Restored Streams and Rivers: A Global Review and Synthesis. Water 2016, 8, 116. [CrossRef]

13. Thurston, H.W.; Taylor, M.A.; Shuster, W.D.; Roy, A.H.; Morrison, M.A. Using a reverse auction to promote household level stormwater control. Environ. Sci. Policy 2010, 13, 405-414. [CrossRef]

14. Hedeen, S. The Mill Creek: An Unnatural History of an Urban Stream; Blue Heron Press/The Rivers Unlimited Mill Creek Restoration Project: Cincinnati, OH, USA, 1994; ISBN 978-0-9643436-0-3.

15. National Weather Service. Cincinnati Climate Graphs. Available online: https://www.weather.gov/iln/ climate_graphs_cvg\# (accessed on 31 October 2018).

16. Homer, C.; Dewitz, J.; Yang, L.; Jin, S.; Danielson, P.; Xian, G.; Coulston, J.; Herold, N.; Wickham, J.; Megown, K. Completion of the 2011 National Land Cover Database for the conterminous United States-representing a decade of land cover change information. Photogramm. Eng. Remote Sens. 2015, 81, 345-354.

17. Soil Survey Staff Web Soil Survey. Available online: https://websoilsurvey.sc.egov.usda.gov (accessed on 29 October 2018).

18. Hamilton County. Cincinnati Area Geographic Information System (CAGIS) Internet Map Server. Available online: https://cagis.hamilton-co.org/ (accessed on 31 October 2018).

19. Midwest Biodiversity Institute (MBI). Biological and Water Quality Assessment of Mill Creek 2016; MBI: Hamilton County, OH, USA, 2016; p. 200. 
20. Consent Decree on Sanitary Sewer Overflows, Wastewater Treatment Plants and Implementation of Capacity Assurance Program Plan for Sanitary Sewer Overflows (Civil Action No. C-1-02-107). Available online: http://www.msdgc.org/consent_decree/Global_consent_decree/index.html (accessed on 26 September 2017).

21. Metropolitan Sewer District of Greater Cincinnati. Lick Run Watershed Master Plan; Metropolitan Sewer District of Greater Cincinnati: Cincinnati, OH, USA, 2012; p. 115.

22. Clohessy, E.; Weidl, C.; Moyer, J.; Lehmann, A.; Koehler, B.; Wamsley, B.; Miller, M.; Merrill, K. Nine-Element Nonpoint Source Implementation Strategic Plan (NPS-IS Plan); Congress Run-Mill Creek HUC-12 (05090203 01 04); Mill Creek Watershed Council of Communities: Cincinnati, OH, USA, 2017; p. 62.

23. Mill Creek Watershed Council of Communities. Lower Mill Creek Watershed Action Plan; Mill Creek Watershed Council of Communities: Cincinnati, OH, USA, 2014; p. 360.

24. Mills, M.; Álvarez-Romero, J.G.; Vance-Borland, K.; Cohen, P.; Pressey, R.L.; Guerrero, A.M.; Ernstson, H. Linking regional planning and local action: Towards using social network analysis in systematic conservation planning. Biol. Conserv. 2014, 169, 6-13. [CrossRef]

25. Mulvaney, K.K.; Lee, S.; Höök, T.O.; Prokopy, L.S. Casting a net to better understand fisheries management: An affiliation network analysis of the Great Lakes Fishery Commission. Mar. Policy 2015, 57, $120-131$. [CrossRef]

26. Paletto, A.; Hamunen, K.; De Meo, I. Social network analysis to support stakeholder analysis in participatory forest planning. Soc. Nat. Resour. 2015, 28, 1108-1125. [CrossRef]

27. Faust, K. Centrality in affiliation networks. Soc. Netw. 1997, 19, 157-191. [CrossRef]

28. Field, S.; Frank, K.A.; Schiller, K.; Riegle-Crumb, C.; Muller, C. Identifying positions from affiliation networks: Preserving the duality of people and events. Soc. Netw. 2006, 28, 97-123. [CrossRef]

29. Scott, J.; Carrington, P.J. The SAGE Handbook of Social Network Analysis; SAGE Publications: London, UK, 2011.

30. Helms, M.M.; Nixon, J. Exploring SWOT analysis-Where are we now? A review of academic research from the last decade. J. Strategy Manag. 2010, 3, 215-251. [CrossRef]

31. Wasserman, S.; Faust, K. Social Network Analysis: Methods and Applications; Cambridge University Press: Cambridge, UK, 1994; Volume 8.

32. Prell, C.; Hubacek, K.; Reed, M. Stakeholder analysis and social network analysis in natural resource management. Soc. Nat. Resour. 2009, 22, 501-518. [CrossRef]

33. Janssen, M.A.; Bodin, Ö.; Anderies, J.M.; Elmqvist, T.; Ernstson, H.; McAllister, R.R.; Olsson, P.; Ryan, P. Toward a network perspective of the study of resilience in social-ecological systems. Ecol. Soc. 2006, 11. Available online: http://www.ecologyandsociety.org/vol11/iss1/art15/ (accessed on 8 April 2019). [CrossRef]

34. Borgatti, S.P.; Mehra, A.; Brass, D.J.; Labianca, G. Network analysis in the social sciences. Science 2009, 323, 892-895. [CrossRef] [PubMed]

35. Ernstson, H.; Barthel, S.; Andersson, E.; Borgström, S.T. Scale-crossing brokers and network governance of urban ecosystem services: The case of Stockholm. Ecol. Soc. 2010, 15, 28. [CrossRef]

36. Ohio Environmental Protection Agency Ohio Nonpoint Source Pollution Control Program; Nine-Element Nonpoint Source Implementation Strategies (9-Element NPS-IS) in Ohio. Available online: https:/epa.ohio. gov/dsw/nps/index\#120845160-9-element-nps-is (accessed on 31 December 2018).

37. 2018 Green Cincinnati Plan; City of Cincinnati: Cincinnati, OH, USA, 2018; p. 273.

38. Wiggins, M.; Repasky, R.; Jeter, L.; Cogen, R. A Framework for Ecosystem Restoration of the Ohio River and Its Watershed; Ohio River Foundation: Blue Ash, OH, USA, 2004; p. 43.

39. Ohio-Kentucky-Indiana Regional Council of Governments (OKI). Water Quality Management Plan for Butler, Clermont, Hamilton, and Warren Counties; OKI Regional Council of Governments: Cincinnati, OH, USA, 2014; p. 722.

40. Metropolitan Sewer District of Greater Cincinnati Final Wet Weather Improvement Plan; Case 1:02-cv-00107-SAS-TSH.; Document 412-3; Metropolitan Sewer District of Greater Cincinnati: Cincinnati, $\mathrm{OH}, \mathrm{USA}, 2010$; p. 51.

41. Fuller, Mossbarger, Scott and May; Greenways Incorporated; Biohabitats, Inc.; Rhinoworks. Mill Creek Watershed Greenway Master Plan; Mill Creek Watershed Council: Cincinnati, OH, USA, 1999; p. 181.

42. Plan Cincinnati; A Comprehensive Plan for the Future; Cincinnati City Council: Cincinnati, OH, USA, 2012; p. 246.

43. Corburn, J. Confronting the challenges in reconnecting urban planning and public health. Am. J. Public Health 2004, 94, 541-546. [CrossRef] 
44. Lane, M.B.; McDonald, G. Community-based environmental planning: Operational dilemmas, planning principles and possible remedies. J. Environ. Plan. Manag. 2005, 48, 709-731. [CrossRef]

45. Hum, T. Planning in neighborhoods with multiple publics: Opportunities and challenges for community-based nonprofit organizations. J. Plan. Educ. Res. 2010, 29, 461-477. [CrossRef]

46. Heckert, M.; Rosan, C.D. Creating GIS-based Planning Tools to Promote Equity through Green Infrastructure. Front. Built Environ. 2018, 4, 27. [CrossRef]

47. Schilling, J.; Logan, J. Greening the rust belt: A green infrastructure model for right sizing America's shrinking cities. J. Am. Plann. Assoc. 2008, 74, 451-466. [CrossRef]

48. Doucet, B.; Smit, E. Building an urban 'renaissance': Fragmented services and the production of inequality in Greater Downtown Detroit. J. Hous. Built Environ. 2016, 31, 635-657. [CrossRef]

49. Meerow, S.; Newell, J.P. Spatial planning for multifunctional green infrastructure: Growing resilience in Detroit. Landsc. Urban Plan. 2017, 159, 62-75. [CrossRef]

50. Safransky, S. Greening the urban frontier: Race, property, and resettlement in Detroit. Geoforum 2014, 56, 237-248. [CrossRef]

51. Wolch, J.R.; Byrne, J.; Newell, J.P. Urban green space, public health, and environmental justice: The challenge of making cities 'just green enough'. Landsc. Urban Plan. 2014, 125, 234-244. [CrossRef]

52. Hamilton County Rate Affordability Task Force 2016. Hamilton County Affordability Task Force; Hamilton County: Hamilton County, OH, USA, 2016; p. 22.

53. Keeley, M.; Koburger, A.; Dolowitz, D.P.; Medearis, D.; Nickel, D.; Shuster, W. Perspectives on the use of green infrastructure for stormwater management in Cleveland and Milwaukee. Environ. Manag. 2013, 51, 1093-1108. [CrossRef]

54. Midwest Biodiversity Institute (MBI). User Manual for the MSDGC Integrated Prioritization System (IPS) and Data Exploration Tool, Version 2.0; Technical Report MBI/2015-10-10; MSD Project Number 10180900; Midwest Biodiversity Institute: Columbus, OH, USA, 2015; Available online: www.midwestbiodiversityinst.org/ publications/ (accessed on 8 April 2019).

55. Kiker, G.A.; Bridges, T.S.; Varghese, A.; Seager, T.P.; Linkov, I. Application of multicriteria decision analysis in environmental decision making. Integr. Environ. Assess. Manag. 2005, 1, 95-108. [CrossRef]

56. Roe, M.; Mell, I. Negotiating value and priorities: Evaluating the demands of green infrastructure development. J. Environ. Plan. Manag. 2013, 56, 650-673. [CrossRef]

57. Hansen, R.; Pauleit, S. From multifunctionality to multiple ecosystem services? A conceptual framework for multifunctionality in green infrastructure planning for urban areas. Ambio 2014, 43, 516-529. [CrossRef]

58. Wright, H. Understanding green infrastructure: The development of a contested concept in England. Local Environ. 2011, 16, 1003-1019. [CrossRef]

59. Young, R.F.; McPherson, E.G. Governing metropolitan green infrastructure in the United States. Landsc. Urban Plan. 2013, 109, 67-75. [CrossRef]

60. Kane, J.; Tomer, A. Renewing the Water Workforce: Improving Water Infrastructure and Creating a Pipeline to Opportunity; Metropolitan Policy Program at Brooking Institute: Washington, DC, USA, 2018; p. 72.

61. Nichols, E.G.; DeLuca, W.V.; Ebersohl, R.D. Multi-Institutional Collaboration for a Shared Renewable Energy Assessment Curriculum. Nat. Sci. Educ. 2015, 44, 34-42.

62. Water Environment Federation National Green Infrastructure Certification Program. Body of Knowledge, Version 2.0; National Green Infrastructure Certification Program: Alexandria, VA, USA, 2016; p. 32.

63. Rubin, Z.; Kondolf, G.; Rios-Touma, B. Evaluating stream restoration projects: What do we learn from monitoring? Water 2017, 9, 174. [CrossRef]

64. Bernhardt, E.S.; Palmer, M.A.; Allan, J.D.; Alexander, G.; Barnas, K.; Brooks, S.; Carr, J.; Clayton, S.; Dahm, C.; Follstad-Shah, J.; et al. Synthesizing US river restoration efforts. Science 2005, 308, 636-637. [CrossRef]

65. Peters, D.P.; Loescher, H.W.; SanClements, M.D.; Havstad, K.M. Taking the pulse of a continent: Expanding site-based research infrastructure for regional-to continental-scale ecology. Ecosphere 2014, 5, 1-23. [CrossRef]

66. U.S. EPA. Stormwater Best Management Practices (BMP) Performance Analysis; United States Environmental Protection Agency-Region 1: Boston, MA, USA, 2010; p. 232.

67. Golden, H.E.; Hoghooghi, N. Green infrastructure and its catchment-scale effects: An emerging science: Green infrastructure and its catchment-scale effects. Wiley Interdiscip. Rev. Water 2018, 5, e1254. [CrossRef]

68. Green Umbrella StreamBank Regional Water Quality Database. Available online: https://greenumbrella.org/ StreamBank-Database (accessed on 15 February 2019). 
69. Harper, G.E.; Limmer, M.A.; Showalter, W.E.; Burken, J.G. Nine-month evaluation of runoff quality and quantity from an experiential green roof in Missouri, USA. Ecol. Eng. 2015, 78, 127-133. [CrossRef]

70. Dufour, A.P. Escherichia coli: The fecal coliform. In Bacterial Indicators/Health Hazards Associated with Water; ASTM International: West Conshohocken, PA, USA, 1977.

71. DeShon, J.E. Development and Application of the Invertebrate Community Index (ICI). In Biological Assessment and Criteria-Tools for Water Resource Planning and Decision Making; Davis, W.S., Simon, T.P., Eds.; Lewis Publ.: Boca Raton, FL, USA, 1995; Volume 2, pp. 7-244.

72. Ohio Environmental Protection Agency. Biological Criteria for the Protection of Aquatic life: Volume II: Users Manual for Biological Field Assessment of Ohio Surface Waters; Ohio Environ Protection Agency-Division of Water Quality Planning and Assessment: Columbus, OH, USA, 1987; p. 288.

73. Karr, J.R. Assessment of biotic integrity using fish communities. Fisheries 1981, 6, 21-27. [CrossRef]

74. Fausch, K.D.; Karr, J.R.; Yant, P.R. Regional application of an index of biotic integrity based on stream fish communities. Trans. Am. Fish. Soc. 1984, 113, 39-55. [CrossRef]

75. Gammon, J.R. The effects of thermal inputs on the populations of fish and macroinvertebrates in the Wabash River; Indiana Water Resources Research Center, Perdue University: West Lafayette, IN, USA, 1973; p. 123.

76. Gammon, J.R.; Spacie, A.; Hamelink, J.L.; Kaesler, R.L. Role of electrofishing in assessing environmental quality of the Wabash River. In Ecological Assessments of Effluent Impacts on Communities of Indigenous Aquatic Organisms; ASTM International: West Conshohocken, PA, USA, 1981.

77. Yoder, C.O.; Rankin, E.T.; Smith, M.A.; Alsdorf, B.C.; Altfater, D.J.; Boucher, C.E.; Miltner, R.J.; Mishne, D.E.; Sanders, R.E.; Thoma, R.F. Changes in fish assemblage status in Ohio's nonwadeable rivers and streams over two decades. In Proceedings of the American Fisheries Society Symposium; American Fisheries Society: Bethesda, MD, USA, 2005; Volume 45, p. 399.

78. Shuster, W.; Rhea, L. Catchment-scale hydrologic implications of parcel-level stormwater management (Ohio USA). J. Hydrol. 2013, 485, 177-187. [CrossRef]

79. Jarden, K.M.; Jefferson, A.J.; Grieser, J.M. Assessing the effects of catchment-scale urban green infrastructure retrofits on hydrograph characteristics. Hydrol. Process. 2016, 30, 1536-1550. [CrossRef]

80. Pennino, M.J.; McDonald, R.I.; Jaffe, P.R. Watershed-scale impacts of stormwater green infrastructure on hydrology, nutrient fluxes, and combined sewer overflows in the mid-Atlantic region. Sci. Total Environ. 2016, 565, 1044-1053. [CrossRef] [PubMed]

81. Eckart, K.; McPhee, Z.; Bolisetti, T. Performance and implementation of low impact development-A review. Sci. Total Environ. 2017, 607, 413-432. [CrossRef] [PubMed]

82. Scown, M.W.; Flotemersch, J.E.; Spanbauer, T.L.; Eason, T.; Garmestani, A.; Chaffin, B.C. People and water: Exploring the social-ecological condition of watersheds of the United States. Elementa 2017, 5, 64. [CrossRef] [PubMed]

83. Thornbrugh, D.J.; Leibowitz, S.G.; Hill, R.A.; Weber, M.H.; Johnson, Z.C.; Olsen, A.R.; Flotemersch, J.E.; Stoddard, J.L.; Peck, D.V. Mapping watershed integrity for the conterminous United States. Ecol. Indic. 2018, 85, 1133-1148. [CrossRef] [PubMed]

84. Lizotte, R.E.; Shields, F.D.; Knight, S.S.; Cooper, C.M.; Testa, S.; Bryant, C.T. Effects of Artificial Flooding on Water Quality of a Floodplain Backwater. River Res. Appl. 2012, 28, 1644-1657. [CrossRef]

(C) 2019 by the authors. Licensee MDPI, Basel, Switzerland. This article is an open access article distributed under the terms and conditions of the Creative Commons Attribution (CC BY) license (http://creativecommons.org/licenses/by/4.0/). 